Manuscript received: 07.12.2021

Accepted: 13.12.2021

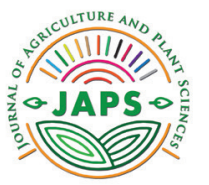

\author{
In print: ISSN 2545-4447 \\ On line: ISSN 2545-4455 \\ doi: https://doi.org/10.46763/JAPS21192037k \\ Original scientific paper
}

\title{
REAL TIME PCR METHOD FOR PPV DIAGNOSTIC ON PLUMS AND APRICOT IN THE REPUBLIC OF NORTH MACEDONIA
}

\author{
Cvetanka Kulukovska ${ }^{1 *}$, Sasa Mitrev' ${ }^{1}$ Emilija Arsov' \\ 'UNILAB laboratory, Department for Plant and Environmental Protection, Faculty of Agriculture, Goce Delcev \\ University - Stip, Republic of North Macedonia \\ *Corresponding author: cecekulukovska@t.mk
}

\begin{abstract}
Real-time PCR (Polymerase Chain Reaction) or qPCR is a method by which the amount of the PCR product can be determined in real-time, and is very useful for investigating gene expression. The main advantages of qPCR are that it provides fast and high-throughput detection and quantification of target DNA sequences in different matrices. The lower time of amplification is facilitated by the simultaneous amplification and visualization of newly formed DNA amplicons. The development and application of molecular methods for the detection of pathogens has significantly changed the diagnosis and control of plant diseases, various environmental samples, including hosts tissues, soil, water and air. With real-time PCR method, it is possible not only to identify and detect the presence or absence of the target pathogen, but it is also possible to quantify the amount present in the sample allowing the quantitative assessment of the number of the pathogen in the sample. Detection and accurate identification of plant pathogens is one of the most important strategies for controlling plant diseases to initiate preventive or curative measures.

Plum pox virus (PPV), the agent of sharka, is the most devastating virus infecting stone fruits. The PPV control is mainly based on prevention, and its quick and reliable detection is considered crucial in this strategy. In this study DAS-ELISA and real-time PCR were compared for evaluating their potentialities and limits for large scale surveys. Plum (Prunus domestica L.) hosts and apricot (Prunus armeniaca L.) samples from several different locations were included in laboratory test analyzes, plant organs (phloem, buds, flowers, leaves and fruits) and parts of them, different seasons (spring, summer and winter period 2017/20), presence or absence of symptoms were considered for comparison. Using DAS-ELISA tests and a universal set of antibodies (BIOREBA), have proved the presence of virus of Plum pox in all examined samples, especially from samples collected in summer, but also in virus status examination in winter and early spring season. The examination found high concentrations of viral antigens in plant samples (OD 2.912-2.752, for $30 \mathrm{~min} / 405 \mathrm{~nm}$ ). Real-time PCR show amplification plot for positive PPV samples on plums and apricot.
\end{abstract}

Keywords: DAS-ELISA tests, real-time PCR, molecular methods, plant disease detection, target pathogen, PPV

\section{INRODUCTION}

Plum pox potyvirus (PPV), the causal agent of sharka disease, is most economically destructive virus diseases affecting stone fruits in Europe and Mediterranean region. The virus is very detrimental because it reduces the quality of fruits and cause a premature dropping (Dunez \& Sutic, 1988; Nemeth, 1994). PPV is considered one of the significant limiting factors for a profitable plum growing, predominately peaches, nectarines, apricots, plums and prunes (Plesko et al., 2011).
Since its discovery, sharka has been considered as a calamity in plum orchards. In highly susceptible plum varieties present in North Macedonia, such as Požegača and Stenlej, PPV causes a premature fruit drop and reduces fruit quality, which leads to total yield loss. The same symptoms and loses are obviously in the peach and cherry orchards. Eight PPV strains (PPV-M, PPV-D, PPV-EA, PPV-C, PPV-Rec, PPV-W, PPV-T and PPV-CR) have been recognized so far. Three major strains (PPV-M, PPV-D and PPV- 
Rec) are the most widely dispersed and occur frequently in many European countries (Bagi et al., 2016, Jevremović, 2012).

DAS-ELISA test (Double antibody sandwich enzyme - linked immunosorbent assay) using BIOREBA kits and One Step Real Time PCR using Applied Biosystems 7500 Real-time PCR System, are one of the most effective molecular diagnostic tools for PPV.

The method of choice for quantification of nucleic acid (DNA, RNA) in all areas of molecular biology is the polymerase chain reaction in real-time or the quantitative $P C R$ ( $\mathrm{PPCR}$ ) method. Quantitative PCR is the "gold standard" technology for quantifying nucleic acids, and since its first report describing realtime PCR detection in 1993, its use has grown exponentially. Newer technological advances expand the range of applications, from highresolution melting detection to digital PCR. Nowadays, it is a very affordable technique to achieve robust and reliable analysis. Real-time PCR (Polymerase Chain Reaction) or $\mathrm{qPCR}$ is a method by which the amount of the PCR product can be determined, in real time, and is very useful for investigating gene expression. The main advantages of $\mathrm{qPCR}$ are that it provides fast and high-throughput detection and quantification of target DNA sequences in different matrices. The lower time of amplification is facilitated by the simultaneous amplification and visualization of newly formed DNA amplicons (EPPO 2004, 2006).

The most obvious is the use of $q P C R$ in molecular diagnostics, where it is slowly replacing conventional methods. It is used to detect, identify and quantify disease-causing microorganisms (bacteria, viruses and fungi). With qPCR the metro decreases, contamination and erroneous results. It also allows large quantities of samples to be processed in less time (up to 384 or even 1536 reactions) and has thus proven to be an indispensable method in diagnostic laboratories. However, it should be noted that the method detects only the presence of DNA or RNA of a microorganism and does not report its viability (Varga \& James, 2005). As a result, conventional microbiological techniques are sometimes still needed along with qPCR, is also used to detect and quantify genetically modified organisms or to perform genotyping. This means that different alleles of the same gene or individual nucleotide polymorphisms (SNPs) can be detected that can be used as genetic diagnostic or prognostic markers for certain diseases (Klarik \& Ricchi, 2017).

\section{MATERIAL AND METHODS}

\section{Plant material}

One of the most important strategies for controlling plant diseases is accurate, early detection and identification of plant pathogens. In fact, this is the basis of plant disease management. Improved disease control with appropriate phytosanitary monitoring for identification and diagnosis of viruses, bacteria, fungi, phytoplasmas, nematodes and insects as well as the introduction of new diagnostic methods for detection of pathogenic plants are necessary in order to respond to emerging environmental challenges in agriculture. Detection and accurate identification of harmful plant pathogens is essential to improve plant disease control strategies. Early detection and identification of plant pathogens and viruses provide a basis for understanding their biology and appropriate strategies for controlling that particular pathogen.

\section{Laboratory analyses}

The laboratory analyses of the collected material were completely performed in the UNILAB laboratory at the Department of Plant and Environmental Protection, Faculty of Agriculture.

For direct PPV detection using DAS ELISA Technique, $0.5 \mathrm{~g}$ of fresh leaves were homogenized with tissue homogenizer (BIOREBA, by using Bioreba extraction bags) with $5 \mathrm{ml}$ plant extraction buffer from commercial kit. Different laboratory analyses and methods are used to identify PPV (Plum pox potyvirus), ELISA serological method, and the greatest emphasis is placed on laboratory analysis using state-ofthe-art molecular real-time PCR analysis. DAS ELISA "ready to read plates" were read after 30 and 60 min of incubation at $25^{\circ} \mathrm{C}$ and samples were considered positive if absorbance $\left(A_{405 n \mathrm{~m}}\right)$ was greater than or equal to two times that of 
negative control.

Real-time PCR (quantitative PCR, qPCR) is now a well-established method for the detection, quantification, and typing of different microbial agents in the areas of clinical, veterinary diagnostics, environmental, food safety, plant disease its. Although the concept of PCR is relatively simple, there are specific issues in $\mathrm{qPCR}$. These include the use of correct terminology and definitions, understanding of the principle of PCR, difficulties with interpretation and presentation of data, the limitations of qPCR in different areas of microbial and environmental diagnostics, parameters important for the description of qPCR performance (Fig. 1).

With the increasing amount of sequencing data available, it is literally possible to design qPCR assays for every microorganism (groups and subgroups of microorganisms, etc.) of interest. The main advantages of qPCR are that it provides fast and high-throughput detection and quantification of target DNA sequences in different matrices. The lower time of amplification is facilitated by the simultaneous amplification and visualization of newly formed DNA amplicons. Moreover, qPCR is safer in terms of avoiding cross contaminations because no further manipulation with samples is required after the amplification. Other advantages of $\mathrm{QPCR}$ include a wide dynamic range for quantification (7-8 Log10) and the multiplexing of amplification of several targets into a single reaction. The multiplexing option is essential for detection and quantification in diagnostic qPCR assays that rely on the inclusion of internal amplification controls. The principle of realtime PCR relies on the use of fluorescent dye. In general, the principle of the present method is stated below. The amount of the nucleic acid present into the sample is quantified using the fluorescent dye or using the fluorescentlabelled oligos. When a dye or probe binds with the target template, it releases a fluorochrome which resultantly emits fluorescence for the detector to detect. The detector captures a signal as a positive template amplification. Two types of chemistry are available for the real-time quantitative PCR:

- DNA binding dye (Intercalating dyebased method)

- Sequence-specific probe (Hydrolysis Probe-based detection method)

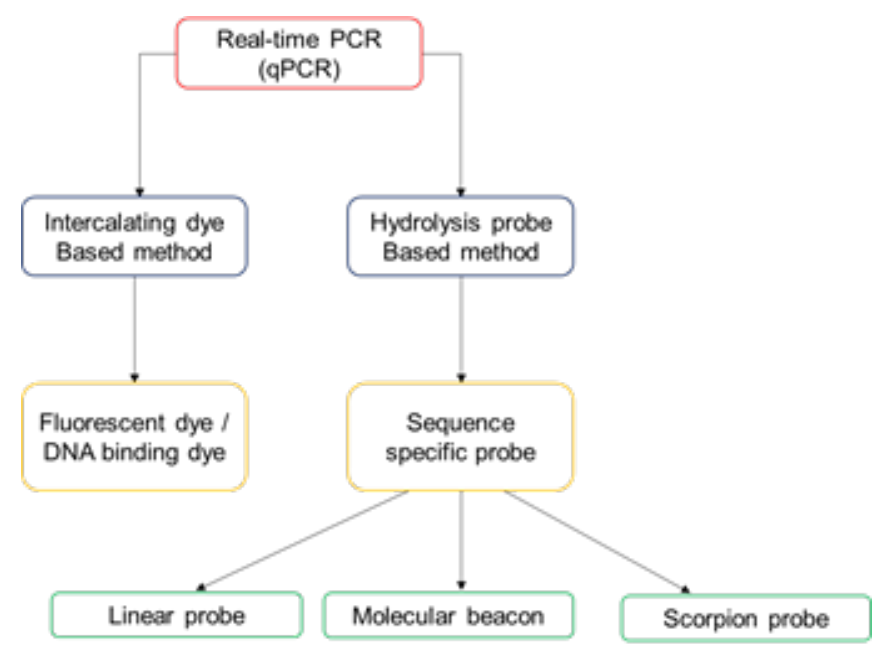

Figure 1. Principle of real-time PCR (qPCR)

If DNA is present in the sample in a higher quantity, amplification and quantification start at the early stage of the reaction; otherwise, the amplification starts in the late stage. As like the conventional PCR, there are three main steps in real-time PCR:

- Denaturation

- Annealing

\section{- Extension}

Denaturation occurs at $94^{\circ} \mathrm{C}$ where the double-stranded DNA is denatured and two single-stranded DNA is generated. The DNA is melted. This single-stranded DNA is the sight of the annealing for the primers in the later step of the amplification. 
Annealing occurs at $55^{\circ} \mathrm{C}$ to $66^{\circ} \mathrm{C}$ in which the sequence-specific primer binds to the single-stranded DNA. Along with it, the fluorescent dye or the probe bind to the DNA sequence too. Extension occurs at $72^{\circ} \mathrm{C}$ at which the Taq DNA polymerase activated highest. In this step, the Taq adds dNTPs to the growing DNA strand. The real-time quantitative PCR is more sensitive and accurate than the endpoint $P C R$. Because, the amplification is measured in real-time, during the reaction. After each reaction, the fluorescence is emitted and it is reported by the detector.

The real-time PCR method is undoubtedly more accurate and reliable than other methods (Kralik \& Ricchi, 2017).

It is used for the quantification of DNA, RNA and gene expression. The sample source for the real-time quantification is gDNA, cDNA, RNA, Gene of interest, synthetic oligos, total RNA or plasmid DNA. The real-time or quantitative analysis is divided into two other methods:

- Standard curve analysis

- Relative quantification

Advantages of Real-time PCR:

1. The method is cost-effective.

2. It is time-efficient

3. More sensitivity and specificity

4. Fewer templates required

DNA binding dye method is the best technique for real-time detection.

The dye has its own fluorescence. Once the dye binds to the double-stranded DNA the fluorescence emitted by the dye increases 100 to 1000 -fold than the original signal. However, the original dye fluorescence is taken as the baseline (as a reference) for the detection.

The method is rapid, quick, reliable and cost-effective. Also, the chance of error in the experiments is less and the reaction setup is simple \& easy to use.

The result of the experiment depends on the specificity of the primers used in the PCR reaction. Because even though the primers remain bound non-specifically, the DNA binding dye binds to the non-specific sequence and gives the fluorescent signals. As the dye detects the double-stranded DNA to bind, even if the dsDNA is non-specific, the dye binds to it. Therefore, the chance of the non-specific detection is high in the SYBR green dye-based method. The SYBR green is one of the most popular dyes used in real-time PCR.
A melting curve analysis helps to identify non-specific bindings during the reaction. After completion of the amplification reaction and capturing fluorescence signals, melting the template (again) determines non-specific bindings if any. During melting, at a high temperature, the template starts denaturing which consequence dye dissociation and reduce fluorescence.

The quantification is achieved by amplifying and monitoring the DNA or RNA present in the sample. For the quantification of the gene expression, the RNA is quantified into the real-time PCR.

Eight PPV strains (PPV-M, PPV-D, PPVEA, PPV-C, PPV-Rec, PPV-W, PPV-T and PPV$(\mathrm{CR})$ have been recognized so far. Three major strains (PPV-M, PPV-D and PPV-Rec) are the most widely dispersed and occur frequently in many European countries. DAS-ELISA test using BIOREBA kits and ONE Step Real Time PCR using Applied Biosystems 7500 Real-Time Laboratory analyses were performed on a 7500 real time PCR instrument with appropriate kits for detection and amplification of Plum pox virus - Plum pox virus One-Step Real-Time PCR with Taq-Man ${ }^{\circledR}$ technology.

The collected material or sample is first RNA extruded by manual method with a suitable plant RNA extraction kit - PureLink ${ }^{\mathrm{TM}}$ RNA Mini Kit which provides a simple, reliable and fast column method for isolating high quality total RNA from a wide range of samples without the need for hazardous reagents such as phenol (RNeasy Plant Mini kit (Qiagene, USA).

The resulting RNA is then used for further laboratory analysis. The used kit for detection and amplification of Plum pox virus - Plum pox virus One-Step Real-Time PCR contains: prepared master mix, enzyme for reverse transcription, positive and negative control.

The protocol is entered into the real-time polymerase chain reaction instrument with the following conditions given in the appropriate detection kit. follows:

The interpretation of the results is as

The sample is positive:

- When the $\mathrm{Ct}$ value of the gain curve is below or equal to 35 .

The sample is negative:

- When there is no amplification curve 
- When the $\mathrm{Ct}$ value of the gain curve is higher than 35 .

The cDNA od each sample was used in separate real-time $P C R$ reactions for detection of PPV. The $20 \mu \mathrm{l}$ real-time PCR reactions for PPV were performed in $1 \mathrm{H}$ TaqMan Universal Master Mix (combine 19,375 $\mu$ l of the PPV Master Mix with $0.625 \mu \mathrm{l}$ of the RT-Enzyme per reaction, and $1 / 10$ diluted CDNA as a template.
Real-time PCR reactions were run in duplicates for each undiluted or dilute CDNA on Applied Biosystems 7500 Real-time PCR Systems, using cycling conditions for the Onestep Real-time RT-PCR kit $\left(55^{\circ} \mathrm{C}\right.$ for 15 min., $95^{\circ} \mathrm{C}$ for $10 \mathrm{~min} ., 5^{\circ} \mathrm{C}$ for $15 \mathrm{sec}$. (denaturation) and $60^{\circ} \mathrm{C}$ for $60 \mathrm{sec}$. (annealing and elongation). Data were acquired and analysed using the 7500 Real-time PCR System Sequence Detection System Software v2.3.

\section{RESULTS AND DISCUSSION}

In our paper, plum (Prunus domestica L.) hosts and apricot (Prunus armeniaca L.) samples from several different locations were included in laboratory test analyses, plant organs (phloem, buds, flowers, leaves and fruits) and parts of them, in different seasons (spring, summer and winter period 2017/20), presence or absence of symptoms were considered for comparison (Fig. 2 \& 3). DAS-ELISA and One Step Real Time $P C R$ techniques are included to confirm the presence and concentration of PPV in different plant material (leaves, stem, flower and fruits). Using DAS-ELISA tests and universal set of antibodies (BIOREBA), has proved the presence of virus of Plum pox in all examined samples, especially in samples collected in winter and early spring season. The examination found high concentrations of viral antigens in leaves samples (OD 2.912-2.752, for $30 \mathrm{~min}, 405 \mathrm{~nm}$ ) (Fig. 4).

Total RNA extraction and quality of extracted tot RNA was different between plant samples. The quality of totRNA from plum samples was high and uniform while quality of totRNA from apricot samples was much lower (data not shown).

Real-time PCR show amplification plot for positive samples (Fig. 5). For Real-time diagnostic we used One-Step Real Time RTPCR kit for Detection of Plum pox potyvirus, by running method using the following conditions and pre-heat the thermal cycler block to $45^{\circ} \mathrm{C}$.

Real-time positive sample is:

$\mathrm{Ct}$ value of the gain curve is below or equal to 35 ( $\mathrm{Ct}=30$ for our PPV positive samples)

The sample is negative:

When there is no amplification curve (negative control)

When the $\mathrm{Ct}$ value of the gain curve is higher than 35 (some of our plum and apricot samples) (Fig. 5b)

As expected, results have proved presence of Plum pox potyvirus (PPV) in plums and apricot in Eastern part of our country. The results were supported by application of state-of-the-art molecular methods for rapid, accurate detection and quantification of pathogenic viruses.

The results from laboratory testing and quantification of PPV from plum and apricot samples, showed that the highest concentrations of viral antigens were found in leaves, followed by flowers and stem, but the samples from fruits did not showed presence of PPV. The latest might be due to very low titter of antigen and they cannot be identified by DASELISA. 


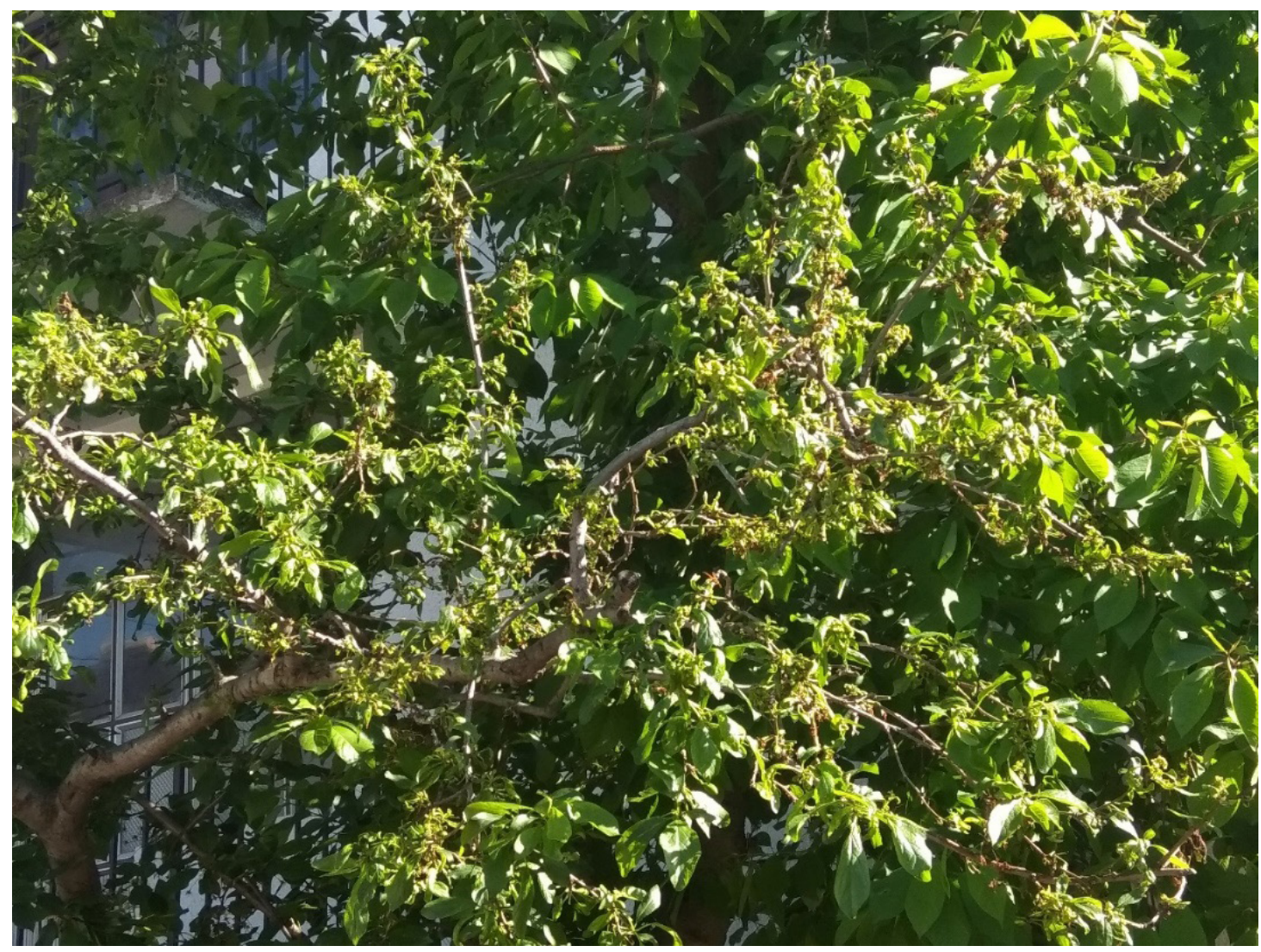

Figure 2. Symptoms caused by PPV on plums (season 2019) - small and morphology deformation.

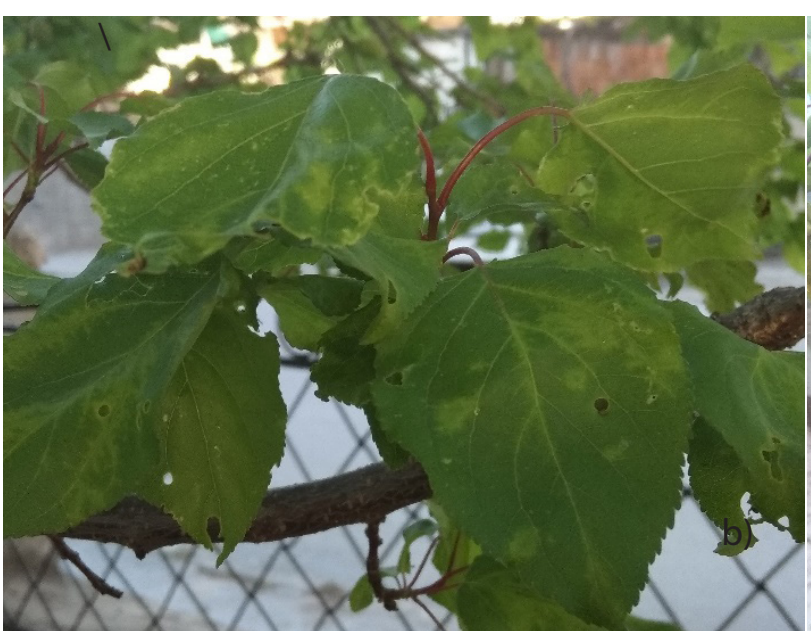

a)

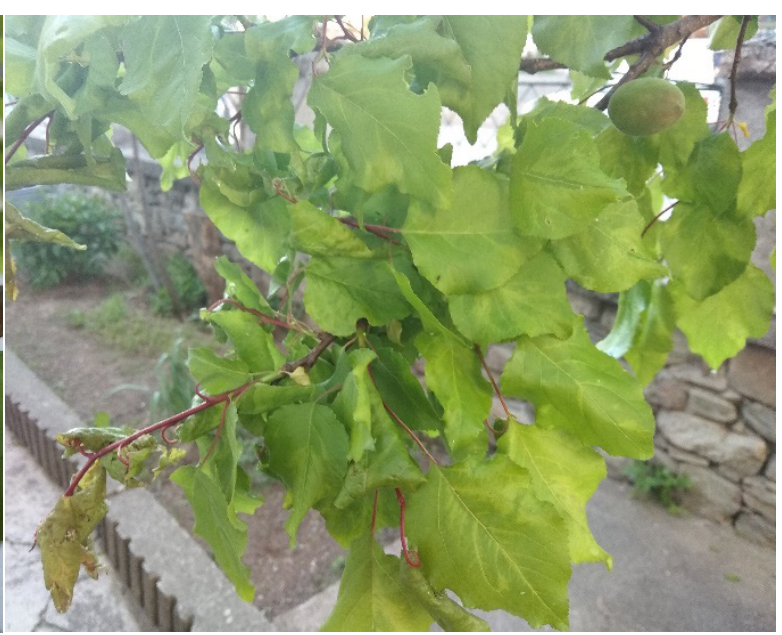

b)

Figure 3. PPV symptoms on apricot (season 2020)

a) Chlorotic rings on apricot leaves.

b) Chlorosis on leaves and morphological deformation on fruits. 


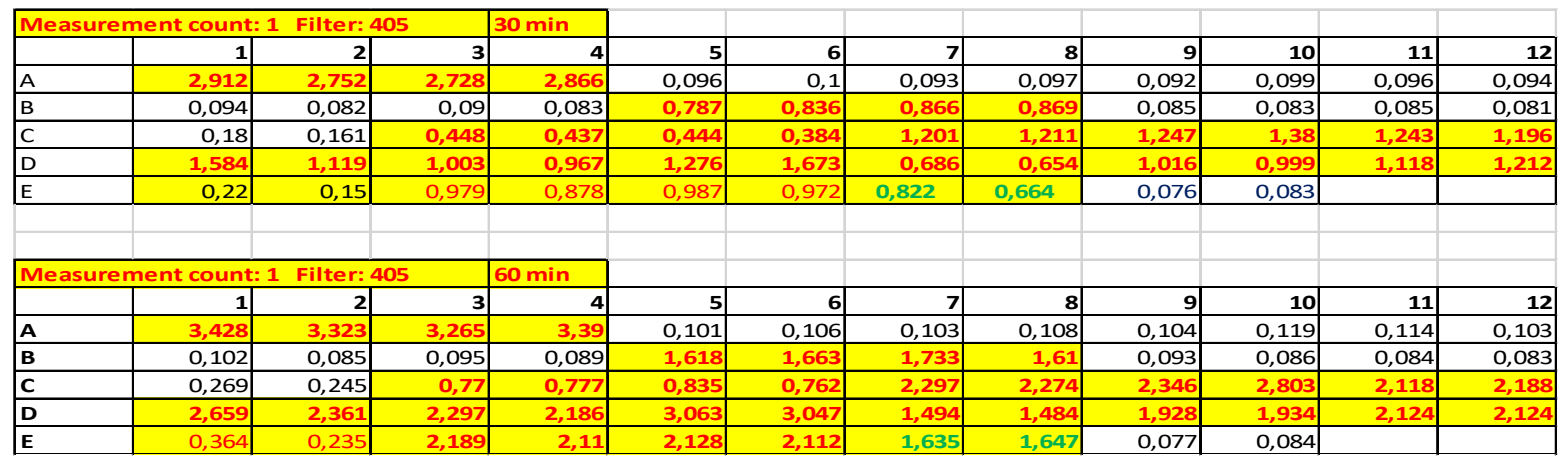

Figure 4. Measurement count on ELISA reader, OD $405 \mathrm{~nm}$, after 30- and 60-min. Green number is referring positive control and the last number from the plate is negative reference control. Yellow coloring indicates all our positive samples from plums in row $A, B, C$ and $D$ and $E$ indicates apricot positive samples.

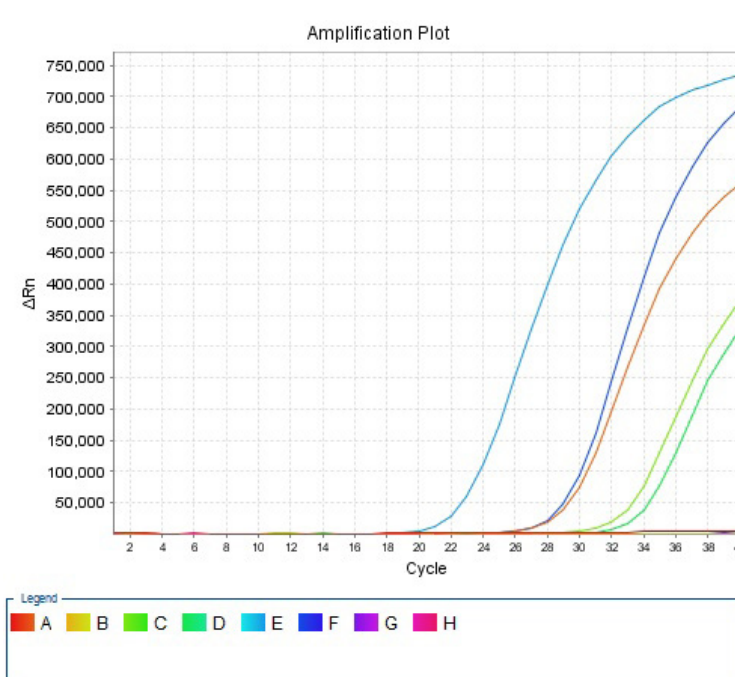

a)

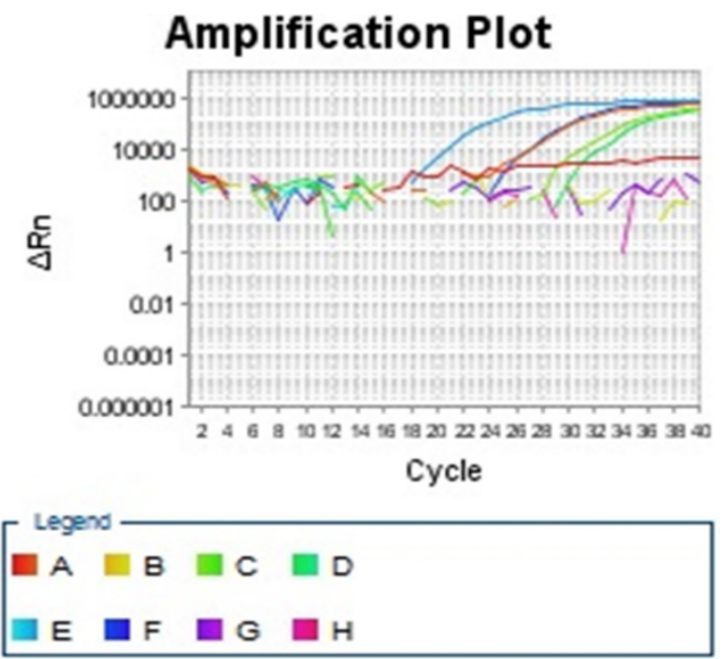

b)

Figure 5. One step Real Time PCR results from plum and apricot samples 2018/19 (using One-Step Real-time RT-PCR Kit, Taq-Man technology).

a) Amplification curves associated to Prunus (blue curves for plum and green for apricot) and red line for negative control (healthy plant)

b) Amplification plot for positive Prunus samples, negative samples and negative control.

\section{CONCLUDING REMARKS}

One of the most important strategies for controlling plant diseases is accurate, early detection and identification of plant pathogens. In fact, this is the basis of plant disease management. Improved disease control with appropriate phytosanitary monitoring for identification and diagnosis of viruses, bacteria, fungi, phytoplasmas, nematodes and insects as well as the introduction of new diagnostic methods for detection of pathogenic plants are necessary in order to respond to emerging environmental challenges in agriculture.

Plant pathogens and viruses infect a wide range of plant species and cause high losses of yields crop quality. Detection and accurate identification of harmful plant pathogens is essential to improve plant disease control strategies. Early detection and identification of plant pathogens and viruses provides a basis for understanding their biology and appropriate strategies for controlling that particular pathogen.

PCR based methods, including realtime PCR are widely used for the detection of plant viruses. In the viral status detection, the most important method is choice of nucleic acid extraction procedure which can greatly influence the reliability of detection and 
quantification of target sample. It is important to validate the extraction procedure for different sample matrixes and the ability of the extraction method to provide suitable nucleic acid from each matrix.

Utilization of DAS-ELISA tests and universal set of antibodies (BIOREBA), has proved the presence of virus status of Plum pox in all examined samples from plum and apricot, especially in samples collected during winter and early spring season. The results showed high concentrations of viral antigens in leaves samples (OD 2.912-2.752, for $30 \mathrm{~min}, 405 \mathrm{~nm}$ ). The universal reagents in the DAS-ELISA format are detecting the 'full spectrum' of PPV isolates (D, M, EA, C, W and Rec strains). In our study, we have much more samples detected by DASELISA as positive, but we didn't confirm all of them by real-time PCR.

For real-time diagnostic we used One-Step Real Time RT-PCR kit and real time PCR, and premethod of total RNA extraction by using Plant Mini Kit (Qiagene, USA). The results showed amplification plot for positive plum and apricot samples, randomly chosen ELISA positive samples were used for totRNA quantification. According to our results we would recommend utilization of different method and commercial kit for totRNA extraction and afterwards usage of cDNA dilute $1 / 10$ in real-time.

Quantitative real-time PCR is an accurate, fast, sensitive, cheap and adequate method in genomic research. Real-time PCR has provided a significant value during pandemics or epidemics for sensitive, real-time and rapid detection of pathogens to reduce the mortality and morbidity rate. Real time PCR method is methodology that is used very often today in our country nowadays in human medicine diagnostics, but previously it was intensively exploited in plant pathology. qPCR technology represents a powerful tool in microbial, environmental, food, plant diagnostics.

\section{ACKNOWLEDGEMENT}

All laboratory work presented in this paper was carried at the Department of Plant and Environmental Protection, UNILAB laboratory (https://unilab.ugd.edu.mk/), at Faculty of Agriculture, Goce Delcev University, Stip.

\section{REFERENCES}

Bagi, F., Jasnić, S. \& Budakov, D. (2016). Plant viruses. University of Novi Sad, Novi Sad.

Dunez, J. \& Dutic, D. (1988): Plum pox potyvirus. European handbook of plant disease, Eds. I.M. Smith, J. Dunez, R.A. Eliot, D.H. Pjillips, S.A. Arches, Blackwell, London, 44-46.

Jevremović, D. (2012). Prevalence of PPV - $D$ and PPV - Rec species of hinge virus in plum in Serbia and dynamics of their spread in plum plantations, doctoral dissertation, Belgrade.

EPPO (2004). Diagnostic protocol for regulated pests: Plum pox potyvirus. Bulletin OEPP/EPPO Bulletin, 34: 247-256.

EPPO (2006). Current status of Plum pox potyvirus and sharka disease worldwide. Bulletin OEPP/EPPO Bulletin, 36: 205-218.

Klarik, P. \& Ricchi, M. (2017): A Basic Guide to Real Time PCR in Microbial Diagnostics: Definitions, Parameters, and Everything. Frontiers in Microbiology, Vol.8, Article 108.

Nemeth, M. (1994): History and importance of plum pox in stone-fruit production. EPPO Bull. 24: 525-536.

Plesko, M. I., Marn V.M., \& Toplak N. (2011). Total RNA extraction method and Prunus species influence the detection of Plum pox potyvirus buy real-time RT-PCR. Acta agriculturae Slovenica, pp 105-113.

Varga, A. \& James, D. (2005). Detection and differentiation of Plum pox potyvirus using real-time multiplex PCR with SYBR Green and melting curve analysis: a rapid method for strain typing. Journal of Virological Methods, 123: 213220. 


\title{
УПОТРЕБА НА МЕТОД ПОЛИМЕРАЗНО ВЕРИЖНА РЕАКЦИЈА ВО РЕАЛНО ВРЕМЕ ЗА ДИЈАГНОСТИКА НА ШАРКА КАЈ СЛИВИ И КАЈСИИ ВО РЕПУБЛИКА СЕВЕРНА МАКЕДОНИЈА
}

\author{
Цветанка Кулуковска ${ }^{1 *}$, Саша Митрев ${ }^{1}$, Емилија Арсов ${ }^{1}$ \\ 'УНИЛАБ лабораторија, Катедра за заштита на растенијата и животната средина, Земјоделски \\ факултет, Универзитет „Гоче Делчев" - Штип, Република Северна Македонија \\ *онтакт автор: cecekulukovska@t.mk
}

\begin{abstract}
Резиме
Полимеразна верижна реакција во реално време real time PCR (Real time Polymerase Chain Reaction) или qPCR е метод со кој количината на PCR производот може да се одреди во реално време и е многу корисен за истражување на генетската експресија. Главните предности на qPCR се тоа што обезбедува брза и високопропусна детекција и квантификација на целните ДНК секвенци во различни матрици. Краткото време на амплификација е олеснето со истовремено засилување и визуелизација на новоформираните ДНК ампликони. Развојот и примената на молекуларните методи за откривање на патогени значително ја промени дијагнозата и контролата на болестите на растенијата, различни примероци од животната средина, вклучувајќ ги ткивата на домаќините, почвата, водата и воздухот. Со методот на PCR во реално време, можно е не само да се идентификува и открие присуството или отсуството на целниот патоген, туку исто така е можно да се измери количината присутна во примерокот што овозможува квантитативна проценка на бројот на патогенот во примерокот. Откривањето и точната идентификација на растителните патогени е една од најважните стратегии за контрола на растителните болести за да се иницираат превентивни или куративни мерки.

Вирусот на шарка кај сливата (PPV) е најопасниот вирус што го инфицира коскестото овошје. Контролата на PPV главно се заснова на превенција, а нејзиното брзо и сигурно откривање се смета за клучно во оваа стратегија. Во оваа студија, DAS-ELISA и PCR во реално време беа споредени за евалуација на нивните потенцијали и граници за истражувања од големи размери. Домаќините на PPV сливата (Prunus domestica L.) и примероците од кајсијата (Prunus armeniaca L.) од неколку различни места беа вклучени за лабораториски тест анализи, со колекционирање на растителни органи (флоем, пупки, цвеќиња, лисја и плодови) и делови од нив во различни периоди од годината (пролет, летен и зимски период 2017-2020) и присуството или отсуството на симптоми беа земени како важен фактор за споредба. Со користење на DAS-ELISA тестови и употреба на универзален сет на антитела (BIOREBA) е докажано присуството на вирусот на шарка кај сливата во сите испитани примероци од слива и кајсија, особено од примероците собрани во лето, но и при проверка на статусот на вирусот во зима и рана пролетна сезона. Тестирањето откри високи концентрации на вирусни антигени во растителните примероци (OD 2,912-2,752 за 30 мин. / $405 \mathrm{~nm}$ ). PCR во реално време прикажува амплификација за позитивни примероци PPV на сливи и кајсија.
\end{abstract}

Клучни зборови: DAS-ELISA tests, real-time PCR, молекуларни методи, патоген, PPV. 